\title{
Association between APOBEC3s and HPV16 E2 gene hypermutation in Uygur females with cervical cancer
}

\author{
SHUANG SUI, ZHEN JIAO, HONGXIANG CHEN, MAYINUER NIYAZI and LIN WANG \\ Department of Obstetrics and Gynecology, People's Hospital of Xinjiang Uygur Autonomous Region, \\ Urumqi, Xinjiang Uygur Autonomous Region 830001, P.R. China
}

Received March 14, 2019; Accepted January 15, 2020

DOI: 10.3892/ol.2020.11697

\begin{abstract}
The present study aimed to investigate whether apolipoprotein B mRNA-editing enzyme catalytic polypeptides (A3) are involved in the regulation of cervical cancer development and human papilloma virus (HPV)16 sustained infection in Uighur females. Cervical tissues of Uygur patients with HPV16 with cervical lesions were collected. Expression levels of $\mathrm{A} 3 \mathrm{C}, \mathrm{A} 3 \mathrm{~F}$ and $\mathrm{A} 3 \mathrm{G}$ were detected using reverse transcription-quantitative PCR and western blotting. A model of $\mathrm{SiHa}$ cells with high expression levels of $\mathrm{A} 3 \mathrm{C}, \mathrm{A} 3 \mathrm{~F}$ and A $3 \mathrm{G}$ was constructed. Hypermutation was detected using the differential DNA denaturation PCR and positive samples were amplified and sequenced. There were significant differences in A3 expression levels in cervical lesions of different grades. $\mathrm{A} 3 \mathrm{C}$ and $\mathrm{A} 3 \mathrm{~F}$ mRNA and protein expression in cervical cancer tissues were significantly lower, whereas the A3G mRNA and protein expression levels were significantly higher compared with the cervicitis and cervical intraepithelial neoplasia (CIN) I-III groups. Hypermutation rates were increased with cervical lesion development. $\mathrm{C}>\mathrm{T}$ and $\mathrm{G}>\mathrm{A}$ base substitutions were detected in all hypermutation samples and numbers of $\mathrm{C}>\mathrm{T}$ and $\mathrm{G}>\mathrm{A}$ base substitutions in single samples in the cervical cancer group were significantly higher compared with those in the CIN I-III and cervicitis groups. Following transfection of A3F and A3G, HPV E2 mRNA and protein expression levels were significantly decreased in $\mathrm{SiHa}$ cells. Numerous $\mathrm{C}>\mathrm{T}$ and $\mathrm{G}>\mathrm{A}$ base substitutions were detected in the HPV E2 gene in A3G and A3C overexpressing $\mathrm{SiHa}$ cells. A3 family proteins inhibit viral replication during HPV16 infection and regulate the HPV16 integration by
\end{abstract}

Correspondence to: Dr Mayinuer Niyazi or Dr Lin Wang, Department of Obstetrics and Gynecology, People's Hospital of Xinjiang Uygur Autonomous Region, 91 Tianchi Road, Urumqi, Xinjiang Uygur Autonomous Region 830001, P.R. China

E-mail: mynr68@126.com

E-mail: Wang930208@163.com

Key words: cervical cancer, apolipoprotein B mRNA-editing enzyme catalytic polypeptides, HPV16 E2 gene, hypermutation, human papilloma virus inducing $\mathrm{C}>\mathrm{T}$ and $\mathrm{G}>\mathrm{A}$ hypermutations in the HPV16 $\mathrm{E} 2$ gene, thus affecting the cervical cancer pathogenesis and development.

\section{Introduction}

Apolipoprotein B mRNA-editing enzyme catalytic polypeptides 3 (A3) are a class of intracellular innate immune protein molecules with antiviral abilities in humans (1). The A3 family has seven members, including APOBEC3A, B, $\mathrm{C}, \mathrm{D} / \mathrm{E}, \mathrm{F}, \mathrm{G}$ and $\mathrm{H}$ (1). The A3 family members can edit the negative DNA strand generated during reverse transcription of a virus, changing cytosine (C) into uracil (U), thereby transforming guanine $(\mathrm{G})$ into adenine $(\mathrm{A})$ at corresponding sites on the positive DNA strand and finally leading to the C/G-to-thymine (T)/A hypermutation in the viral genome (2). Overall, the mutant viral genome is degraded by U DNA transglucosylase and the hypermutation in the negative DNA strand blocks the replication of the positive strand, thereby inhibiting viral replication (2).

The members of the A3 family have been demonstrated to induce the C/G-to-T/A hypermutation in the human immunodeficiency virus (HIV) genome and to subsequently inhibit viral replication (3-6). Luo et al (7) have demonstrated that APOBEC 3F $(\mathrm{A} 3 \mathrm{~F})$ induces a $\mathrm{G}>\mathrm{A}$ mutation in the genome of porcine endogenous retrovirus (PERV) through a cytidine deamination mechanism, thereby inhibiting PERV replication. Additionally, Noguchi et al (8) have reported that high expression levels of APOBEC3G (A3) protein in HepG2 cells significantly reduce synthesis of the hepatitis $\mathrm{B}$ virus (HBV) and induce the genomic hypermutation. Vieira et al (9) reported that the infection of high-risk human papillomavirus (HPV) upregulates mRNA and protein expression levels of APOBEC3B (A3B). After infection with inactivated HPV E6, the HPV infection is no longer able to regulate expression levels of A3B. It has been revealed that A3 can also target DNA viruses requiring no reverse transcription when replicating, including the TT virus, adeno-associated virus and herpes simplex virus 1 (10-13). A number of studies have demonstrated that $\mathrm{A} 3$ serve an important role in mediating the clearance of exogenous circular DNA from cells, which may clear the HPV genome in persistently infected cells, and that the APOBEC protein may be a driver for the HPV genomic mutations in cervical precancerous lesions (14-16). 
Kondo et al (17) have reported that A3A is highly expressed in patients with oropharyngeal cancer, which is involved in the regulation of HPV16 infection and the integration in oropharyngeal cancer.

HPV is a non-enveloped double-stranded DNA virus of $\sim 8 \mathrm{~kb}$. The genome can be divided into the following three regions: The long control region (LCR); early region, containing 6 open reading frames (ORFs), including E1, E2, E4, E5, E6 and E7; and late regions, containing the L1 and L2 ORFs. Among these regions, E6 and E7 are key oncogenes which serve important roles in HPV-induced cervical cancer by interfering with the tumor suppressor genes p53 and $\mathrm{pRb}$, thus inhibiting normal cell proliferation $(18,19)$. The complete E2 protein regulates viral mRNA transcription and DNA replication, negatively regulating the expression of E6 and E7 oncogenes $(18,19)$. However, there are few systematic studies concerning APOBEC3s-associated hypermutations in different regions of the HPV genome or the effects of APOBEC3s on HPV protein expression levels, particularly the E2 protein.

To elucidate whether the A3 family members function in the regulation of HPV16 infection and the development of cervical cancer in Uygur females from Xinjiang, China, samples of cervical lesions were harvested from patients with high-risk HPV16 infections and analyzed. The mRNA and protein expressions of the A3 family members were detected. Additionally, the E2 region of the HPV16 genome was amplified using the differential DNA denaturation PCR (3D-PCR), followed by sequence analysis. In addition, to investigate the effects of high expression levels of A3 on the expression and editing of the E2 region of the HPV16 genome, a SiHa cervical cancer cell model expressing high levels of A3 was established in vitro.

\section{Materials and methods}

Patients. Cervical samples were obtained from 45 Uygur females infected with high-risk HPV16(age,42.27 \pm 10.46 years), who were admitted to the People's Hospital of Xinjiang Uygur Autonomous Region (Urumqi, China), from January 2017 to December 2017. According to the pathological diagnosis, there were 15 cases of cervicitis, 15 cases of cervical intraepithelial neoplasia (CIN) I-III and 15 cases of cervical cancer. The International Federation of Gynecology and Obstetrics (FIGO, 2018) staging criteria were used for CIN grading and cervical cancer staging (20). Informed consent was provided by every patient and the study was approved by The Ethics Review Board of the People's Hospital of Xinjiang Uygur Autonomous Region.

Study cell line. The human cervical carcinoma SiHa cell line was purchased from the American Type Culture Collection (HTB-35). The cells were verified by short tandem repeat (STR) testing. The cells were cultured with the Dulbecco's modified eagle medium (11885092; Gibco; Thermo Fisher Scientific, Inc.) containing 10\% fetal bovine serum (CCS30013.01HI; EnmoAsai Biotechnology Co., Ltd., Changzhou, China; http://www.mrcing.com/col.jsp?id=105), supplemented with $1 \%$ penicillin-streptomycin $(10,000 \mathrm{U} / \mathrm{ml})$ (15140122; Gibco) and incubated at $37^{\circ} \mathrm{C}$ with $5 \% \mathrm{CO}_{2}$.
Reverse transcription-quantitative $(R T-q) P C R$. Total RNA was extracted from cervical tissue samples using a Total RNA extraction kit (DP431; Tiangen Biotech Co., Ltd.). The mRNAs of A3C (NM_014508.3), A3F (NM_001006666.2) and A3G (NM_001349436.1) were obtained from the GenBank database (uniprot.org/database/DB-0028) and the ORFs were designed accordingly for the PCR primers (Table I). The extracted RNA was reverse transcribed into cDNA using a PrimeScript ${ }^{\mathrm{TM}} \mathrm{RT}$ reagent kit (cat. no. RR037A; Takara Bio, Inc.). The reaction conditions were $37^{\circ} \mathrm{C}$ for $15 \mathrm{~min}$ and $85^{\circ} \mathrm{C}$ for $5 \mathrm{sec}$. RT-qPCR was performed using an AGS PCR machine (AFD4800; Hangzhou AnYu Technologies Co., Ltd.). The reaction conditions were set as follows: $95^{\circ} \mathrm{C}$ for $2 \mathrm{~min} ; 95^{\circ} \mathrm{C}$ for $5 \mathrm{sec} ; 60^{\circ} \mathrm{C}$ for $10 \mathrm{sec}$; and 72 for $30 \mathrm{sec}$ for a total of 40 cycles. Target gene expression levels were determined with the $2^{-\Delta \Delta \mathrm{Cq}}$ method (21). GADPH was used as an endogenous control.

Western blot analysis. The tissue or SiHa cells were lysed using Biosharp lysis (BL504A). The protein concentration was determined using the bicinchoninic acid assay method. Protein samples (40 $\mu \mathrm{g}$ per lane) were loaded onto a $4 \%$ gel, resolved SDS-PAGE and then subsequently transferred onto a PVDF membrane. After blocking with 5\% BSA at room temperature for $1 \mathrm{~h}$, the membrane was incubated with anti-APOBEC3G (1:500; bs-15407R; BIOSS), anti-APOBEC3F (1:500; ab227962; Abcam), anti-APOBEC3C (1:500; bs-12495R; BIOSS) and anti-GAPDH (1:5,000; bs-50549R; BIOSS) primary antibodies at $4^{\circ} \mathrm{C}$ for $16 \mathrm{~h}$. Subsequently, the membranes were incubated with the secondary antibody of goat anti-rabbit HRP conjugated IgG (1:10,000; ZB-2301; OriGene Technologies, Inc.) at $37^{\circ} \mathrm{C}$ for $1 \mathrm{~h}$ in the dark. The blot was developed using the ECL method (PE0010; Beijing Solarbio Science \& Technology Co., Ltd.). Protein bands were imaged and analyzed using Image J software version $1.52 \mathrm{~s}$ (National Institutes of Health).

Lentiviral vector transfection. The A3C, A3F and A3G lentiviral expression vectors were constructed by Shanghai GeneChem Co., Ltd. The lentiviral expression vectors of PLVX-mCMV-ZsGreen-PGK-Puro-homo-APOBEC3C, PLVX-mCMV-ZsGreen-PGK-Puro-Homo-APOBEC3F and PLVX-mCMV-ZsGreen-PGK-Puro-homo-APOBEC3G were transfected into the SiHa cells using Polybrene (Shanghai GeneChem Co., Ltd.) and Enhanced Infection Solution (Shanghai GeneChem Co., Ltd.), at the multiplicities of infection of 50, 10 and 20, respectively. The blank and scrambled small interfering RNA (siRNA) negative control groups were also set up. The siRNA was synthesized by Shanghai GeneChem Co., Ltd; however, the sequences were not available. Following addition of the lentiviral vectors, the cells were incubated at $37^{\circ} \mathrm{C}$ in a $5 \% \mathrm{CO}_{2}$ incubator for $16 \mathrm{~h}$. Subsequently, the cells were cultured with fresh DMEM for $72 \mathrm{~h}$ prior to collection. The fluorescence intensity was observed using an inverted fluorescence microscope.

3D-PCR amplification and hypermutation analysis of the HPV16 E2 genome. HPV16 DNA was extracted from the cervical tissue samples and SiHa cells using a Genomic DNA Extraction kit (DP304; Tiangen Biotech Co., Ltd.). With the template of HPV16 DNA, the E2 region of the HPV16 genome 
Table I. PCR primer sequences.

\begin{tabular}{ll} 
Gene & \multicolumn{1}{c}{ Primer sequences (5'-3') } \\
\hline $\begin{array}{l}\text { APOBEC3C } \\
\text { Forward } \\
\text { Reverse }\end{array}$ & GAGTGGGACAGGGACAAGCA \\
APOBEC3F & GGCTCAGGATGACCAGGCAG \\
Forward & ATGAAGCCTCACTTCAGAAAC \\
Reverse & TCACTCGAGAATCTCCTGCA \\
APOBEC3G & \\
Forward & TCTGGCTGTGCTACGAAGT \\
Reverse & GTGGAAGAATCTCATCTCTGG \\
GADPH & \\
Forward & TCTCCTCTGACTTCAACAGCGAC \\
Reverse & CCCTGTTGCTGTAGCCAAATTC \\
\hline
\end{tabular}

APBOEC3, apolipoprotein B mRNA-editing enzyme catalytic polypeptide.

was amplified with high-fidelity Taq enzyme (14966005; Thermo Fisher Scientific, Inc.) using 3D-PCR at different denaturation temperatures, at $89.3,87.43,85.2,83.5$ and $81.9^{\circ} \mathrm{C}$. For the first round of PCR, the following primers were used: Forward, 5'-GAGGACGAGGACAAGGAAA-3' and reverse, 5'-AAGCACGCCAGTAATGTTG-3'. The reaction conditions were set as: $89.3^{\circ} \mathrm{C}$ for $1 \mathrm{~min} ; 89.3^{\circ} \mathrm{C}$ for $45 \mathrm{sec}$, $52^{\circ} \mathrm{C}$ for $30 \mathrm{sec}, 65^{\circ} \mathrm{C}$ for $50 \mathrm{sec}$, for a total of 40 cycles; followed by $65^{\circ} \mathrm{C}$ for $10 \mathrm{~min}$. The products were used as the templates for the second round of PCR, with the following primers: Forward, 5'-ACGATGGAGACTCTTTGCC-3' and reverse, 5'-GCCAGTAATGTTGTGGATGC-3'. The reaction conditions were set as follows: $87.4^{\circ} \mathrm{C}$ for $1 \mathrm{~min} ; 87.4^{\circ} \mathrm{C}$ for $45 \mathrm{sec} ; 52^{\circ} \mathrm{C}$ for $30 \mathrm{sec}, 65^{\circ} \mathrm{C}$ for $50 \mathrm{sec}$, for a total of 40 cycles; followed by $65^{\circ} \mathrm{C}$ for $10 \mathrm{~min}$. The obtained products were then used as the templates for the next amplification with lowered denaturation temperatures, ranging between $81.9^{\circ} \mathrm{C}$ and $89.3^{\circ} \mathrm{C}$. The final products were separated by $1.5 \%$ agarose gel electrophoresis. The target fragments were recovered using a Gel Recovery kit (B518131-0100; Sangon Biotech Co., Ltd.) and ligated into the pBS-T vector for transformation. The positive clone was picked up and amplified by liquid LB medium (B540111-0100; Sangon Biotech Co., Ltd.). DNA was extracted from these amplified plasmids, which were subjected to the Sanger sequencing on the ABI3100 sequencer (Xinjiang Dingju Medical Laboratory) (http://dj-medlab. $\mathrm{com} /$ ). The PCR product containing the specified number of C-to-T mutations was cloned into the pBS-T vector to prepare the reference plasmid [NC_001526.4 (1892..2989)] (Xinjiang Dingju Medical Laboratory), which was verified by Sanger sequencing. DNAMAN software version 6.0 (Lynnon Biosoft) was used for sequence alignment.

Statistical analysis. The experiments were performed three times independently. Data are presented as the mean \pm SD. SPSS 16.0 software (SPSS, Inc.) was used for statistical analysis. One-way ANOVA was performed for the comparison of mean values among groups followed by Tukey's post hoc test. $\mathrm{A} \chi^{2}$ test was used to compare the hypermutation ratio. $\mathrm{P}<0.05$ was considered to indicate a statistically significant difference.

\section{Results}

Relative mRNA expression levels of $A 3 C, A 3 F$ and $A 3 G$ in cervical lesions of different grades. To investigate the mRNA expression levels of $\mathrm{A} 3 \mathrm{C}, \mathrm{A} 3 \mathrm{~F}$ and $\mathrm{A} 3 \mathrm{G}$ in cervical tissue samples, RT-qPCR was performed. The mRNA expression levels of $\mathrm{A} 3 \mathrm{C}$ in the cervical cancer group were significantly lower compared with the CIN I-III and cervicitis groups $(\mathrm{P}<0.01$, Fig. 1A). The mRNA expression levels of A3F in the cervical cancer group were significantly lower compared with the cervicitis $(\mathrm{P}<0.05)$ and CIN I-III $(\mathrm{P}<0.01)$ groups (Fig. 1B). The A3G mRNA expression in the cervical cancer group was significantly higher compared with the CIN I-III $(\mathrm{P}<0.05)$ and cervicitis groups $(\mathrm{P}<0.05$, Fig. $1 \mathrm{C})$. These results indicated that, with the development and progression of cervical lesions, the relative mRNA expression levels of $\mathrm{A} 3 \mathrm{C}$ and $\mathrm{A} 3 \mathrm{~F}$ were significantly decreased, whereas the relative A3G mRNA expression levels were significantly increased, suggesting that A3 may be involved in the development of cervical cancer.

Relative protein expression levels of $A 3 C, A 3 F$ and $A 3 G$ in cervical lesions of different grades. To investigate the protein expression levels of $\mathrm{A} 3 \mathrm{C}, \mathrm{A} 3 \mathrm{~F}$ and $\mathrm{A} 3 \mathrm{G}$ in these cervical tissue samples, western blot analysis was performed. The protein expression levels of A3C (Fig. 2A and B) and A3F (Fig. 2A and C) in the cervical cancer group were significantly lower compared with the cervicitis and CIN I-III groups $(\mathrm{P}<0.01)$. The protein expression levels of $\mathrm{A} 3 \mathrm{C}$ and $\mathrm{A} 3 \mathrm{~F}$ in the CIN I-III group were significantly lower than the cervicitis group $(\mathrm{P}<0.01)$. The $\mathrm{A} 3 \mathrm{G}$ protein expression levels (Fig. 2A and C) in the cervical cancer group were significantly higher compared with the cervicitis and CIN I-III groups $(\mathrm{P}<0.01)$. The A3G protein expression levels in the CIN I-III groups were significantly higher compared with the cervicitis group $(\mathrm{P}<0.01)$. These results indicated that, with the development and progression of cervical lesions, the relative protein expression levels of $\mathrm{A} 3 \mathrm{C}$ and $\mathrm{A} 3 \mathrm{~F}$ were significantly decreased, whereas the relative $\mathrm{A} 3 \mathrm{G}$ protein expression levels were significantly increased, suggesting that A3 may be involved in the cervical cancer pathogenesis and development.

3D-PCR detection of the HPV16 E2 gene hypermutation in different grades of cervical lesions. DNA was extracted from the cervical tissues of the patients with cervical cancer and 3D-PCR was performed to detect the HPV16 E2 hypermutation. At the denaturation temperature of $\geq 87.4^{\circ} \mathrm{C}$, the control DNA without mutations [0x base substitution (b.s.)] was amplified and at the denaturation temperature of $85.2^{\circ} \mathrm{C}$ the control DNA carrying $3 \mathrm{C}>\mathrm{T}$ mutants (3x b.s.) was amplified (Fig. 3A), implying that at the denaturation temperature of $\leq 85.2^{\circ} \mathrm{C}$ the hypermutation sample with more than three base substitutions may be detected. Detection of the cervicitis, CIN I-III and cervical cancer groups revealed that in the 15 samples from the patients with cervicitis, hypermutation was detected in one sample at the denaturation temperature of $85.2^{\circ} \mathrm{C}$. For the 15 cases of CIN I-III, hypermutation was detected in 
A

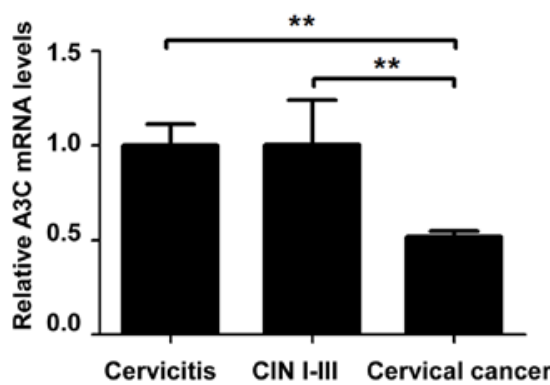

C

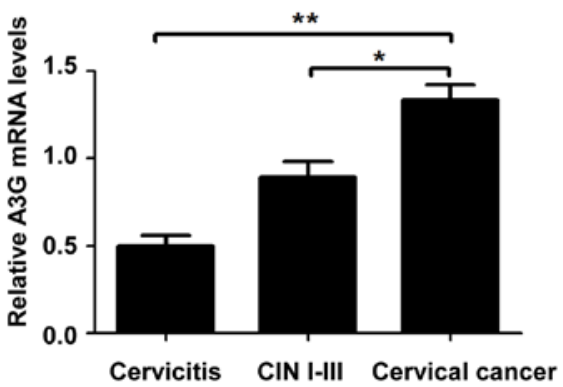

B

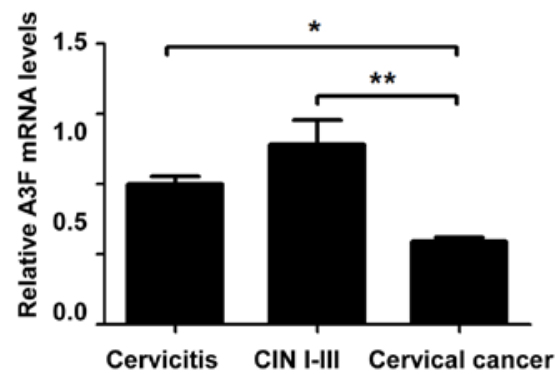

Cervicitis CIN I-III Cervical cancer

Figure 1. Expression levels of APBOEC3s mRNA in cervical lesion samples of the cervicitis, CIN I-III and cervical cancer groups. The relative mRNA expression levels of (A) A3C, (B) A3F and (C) A3G in the cervical lesions of different grades were detected using reverse transcription-quantitative PCR. "P $<0.05$, ${ }^{* *} \mathrm{P}<0.01$. APBOEC3s, apolipoprotein B mRNA-editing enzyme catalytic polypeptides; CIN I-III, cervical intraepithelial neoplasia I, II and III.

A

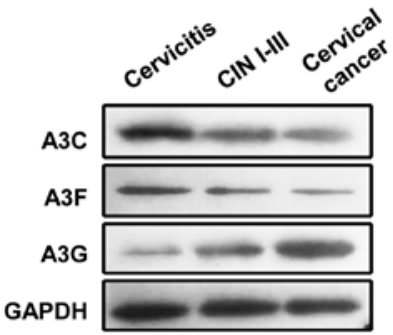

C

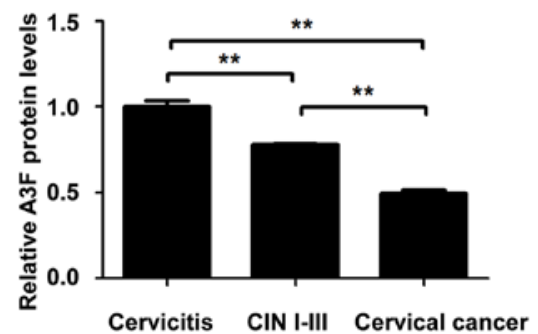

B

D
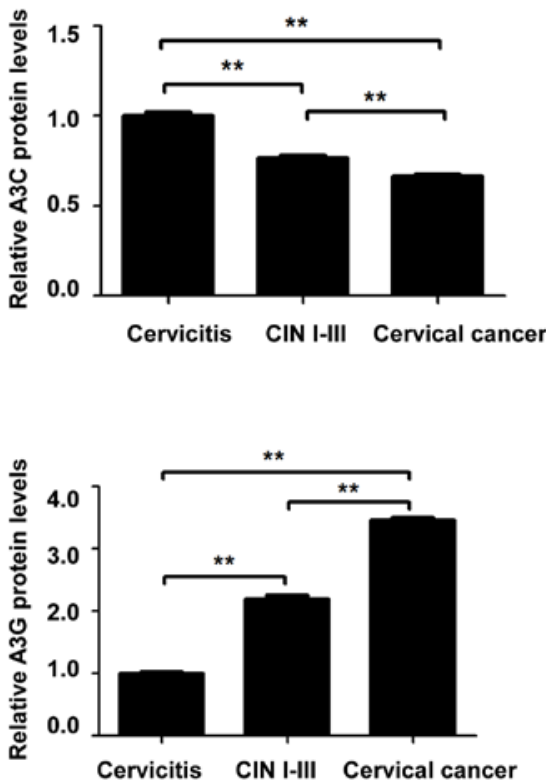

Figure 2. Protein expression levels of APBOEC3 in cervical cancer of different grades. (A) Protein expression levels of A3C, A3F and A3G in cervical lesion of different grades detected using western blot analysis. Relative protein expression levels of (B) A3C, (C) A3F and (D) A3G. ${ }^{* *} \mathrm{P}<0.01$. APBOEC3s, Apolipoprotein B mRNA-editing enzyme catalytic polypeptides; CIN I-III, cervical intraepithelial neoplasia I, II and III.

5 cases at the denaturation temperature of $85.2^{\circ} \mathrm{C}$ and out of these 5 cases hypermutation was detected in 2 cases at the denaturation temperature of $83.5^{\circ} \mathrm{C}$. For the 15 samples of cervical cancer, hypermutation was detected in 5 cases at the denaturation temperature of $85.2^{\circ} \mathrm{C}$ and out of these 5 cases, hypermutation was detected in 3 cases at the denaturation temperature of $83.5^{\circ} \mathrm{C}$ (Table II and Fig. 3A).

For the samples with positive results in the amplification at the melting temperature of $85.2^{\circ} \mathrm{C}$ in the 3D-PCR, Sanger sequencing of the HPV16 E2 gene was performed. The results 
A

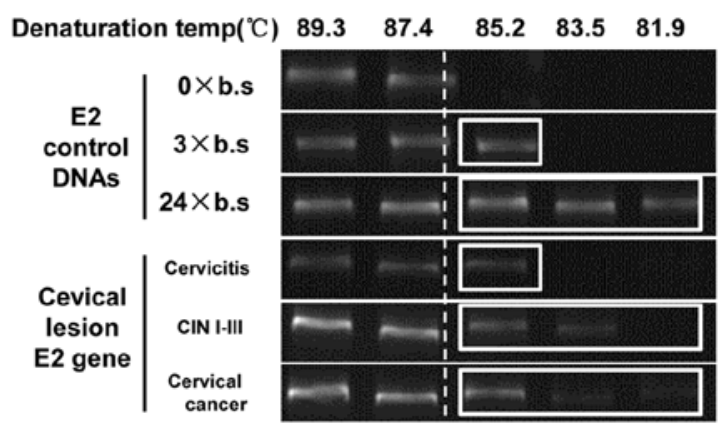

B

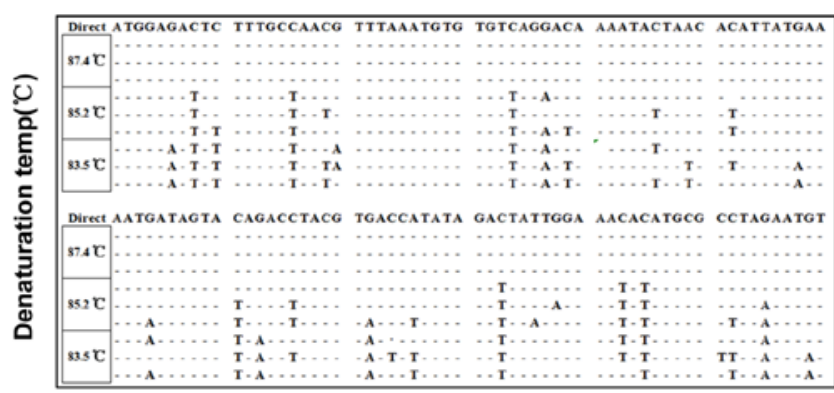

D
C

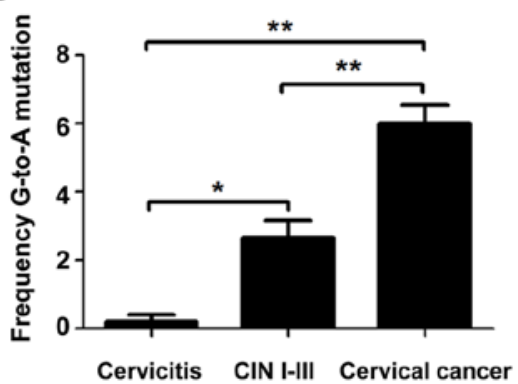

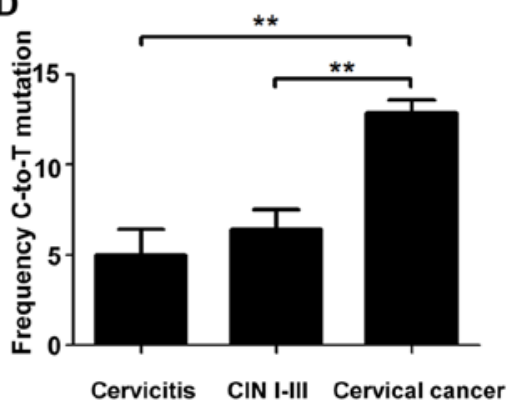

Figure 3. Hypermutation of HPV16 E2 gene in cervical lesions of different grades. The HPV16 E2 gene in cervical tissues was amplified with 3D-PCR at different denaturing temperatures of $89.3,87.4,85.2,83.5$ and $81.9^{\circ} \mathrm{C}$. (A) $0 x$ b.s., $3 x$ b.s. and $24 x$ b.s. were used to construct the reference plasmids with 0,3 and $24 \mathrm{C}$-to-T base substitutions and the denaturation temperatures for the hypermutation were detected in these samples. The $3 \mathrm{x}$ b.s. sample exhibited bands at $85.2^{\circ} \mathrm{C}$. Positive samples were detected for the cervicitis, CIN I-III and cervical cancer groups at the denaturing temperature of $85.2^{\circ} \mathrm{C}$. (B) Base substitutions for the hypermutation in single samples at different melting temperatures of $87.4,85.2$ and $83.5^{\circ} \mathrm{C}$. (C) Frequency of G-to-A mutation. (D) Frequency of C-to-T mutation. ${ }^{*} \mathrm{P}<0.05,{ }^{* *} \mathrm{P}<0.01$. HPV, human papilloma virus; b.s., base substitution; CIN I-III, cervical intraepithelial neoplasia I, II and III; C, cytosine; $\mathrm{G}$, guanine; A, adenine; $\mathrm{T}$, thymine.

revealed that the $\mathrm{C}>\mathrm{T}$ and $\mathrm{G}>\mathrm{A}$ hypermutations were observed in the HPV16 E2 gene (Fig. 3B). The rate of hypermutation in these cervical lesion samples of different grades was further analyzed, revealing that there was no significant difference in the rate of hypermutation among these three groups at the denaturation temperature of $85.2^{\circ} \mathrm{C}\left(\chi^{2}=3.85 ; \mathrm{P}=0.146\right)$. When the temperature was dropped to $83.5^{\circ} \mathrm{C}$, the rate of hypermutation was decreased and there was still no significant difference in the ratio of hypermutation among these three groups $\left(\chi^{2}=3.15\right.$; $\mathrm{P}=0.207$; Table II). Additionally, the number of base substitutions in the single hypermutation sample was analyzed. The number of $\mathrm{G}>\mathrm{A}$ base substitutions in the hypermutation positive cervical cancer cases $(6.00 \pm 2.14)$ was significantly higher compared with those in the CIN I-III $(2.67 \pm 1.95)$ and cervicitis groups $(0.20 \pm 0.45$; both $\mathrm{P}<0.05)$. Furthermore, the number of $\mathrm{C}>\mathrm{T}$ base substitutions in the hypermutation positive cervical cancer cases $(12.87 \pm 2.77)$ was significantly higher

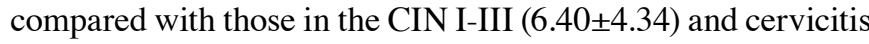
groups (5.00 \pm 3.16 ; both $\mathrm{P}<0.05$; Fig. $3 \mathrm{C}$ and $\mathrm{D})$. These results suggested that HPV16 E2 hypermutation may be increased with the development and progression of cervical lesions.

Expression and hypermutation of HPV E2 in SiHa cells following APOBEC 3s lentivirus transfection. The A3C, A3F and $\mathrm{A} 3 \mathrm{G}$ overexpressing $\mathrm{SiHa}$ cell model was established and the transcriptional level of HPV16 E2 and the E2 hypermutation were investigated. Following transfection of A3F and A3G, the mRNA and protein expression levels of HPV16 E2 in the SiHa cells were significantly decreased compared with those in the blank and the scrambled siRNA negative control groups $(\mathrm{P}<0.01$; Fig. 4A), whereas no significant difference was observed in HPV16 E2 mRNA expression levels between the $\mathrm{A} 3 \mathrm{C}$ transfection and control groups $(\mathrm{P}>0.05)$. The HPV16 E2 gene in the SiHa cells was amplified by 3D-PCR. For the $\mathrm{A} 3 \mathrm{C}$ transfection groups, the hypermutations were observed at the denaturation temperature of $85.2^{\circ} \mathrm{C}$, while no hypermutations were noted at other denaturation temperatures. Moreover, for the $\mathrm{A} 3 \mathrm{G}$ groups, the hypermutations were observed at the denaturation temperatures of $85.2,83.5$ and $81.9^{\circ} \mathrm{C}$. However, no hypermutations were observed at the denaturation temperatures of $85.2,83.5$ or $81.9^{\circ} \mathrm{C}$ in the A3F groups. Then, the hypermutation positive samples in the 3D-PCR were subjected to sequencing. After the transfection of A3 proteins, a larger amount of $\mathrm{G}>\mathrm{A}$ and $\mathrm{C}>\mathrm{T}$ base substitutions were detected in the HPV16 E2 gene in these transfected SiHa cells (Fig. 4B). There were a total of $126 \mathrm{C}>\mathrm{T}$ and $2 \mathrm{G}>\mathrm{A}$ base substitutions in the A3G transfection group and $56 \mathrm{C}>\mathrm{T}$ and $34 \mathrm{G}>\mathrm{A}$ base substitutions in the $\mathrm{A} 3 \mathrm{C}$ transfection group (Table III). These results suggested that the high expression levels of $\mathrm{A} 3$ proteins were associated with the downregulated expression levels of HPV16 E2, and that high A3 expression induced these hypermutation in the HPV16 E2 gene.

\section{Discussion}

High-risk HPV persistent infection is an important factor for cervical cancer and precancerous lesions, which integrate into the host genome after infection and thus induce cervical 
Table II. Association between HPV16 E2 hypermutation and cervical lesions.

\begin{tabular}{|c|c|c|c|c|c|c|}
\hline \multirow[b]{2}{*}{ Group } & \multicolumn{4}{|c|}{$\begin{array}{c}\text { Second-round PCR } \\
\text { denaturing temperature, }{ }^{\circ} \mathrm{C}\end{array}$} & \multirow{2}{*}{$\begin{array}{c}\text { Hypermutation ratio, } \% \\
\left(85.2^{\circ} \mathrm{C} / 87.4^{\circ} \mathrm{C}\right)\end{array}$} & \multirow{2}{*}{$\begin{array}{c}\text { Hypermutation ratio, } \% \\
\left(83.5^{\circ} \mathrm{C} / 87.4^{\circ} \mathrm{C}\right)\end{array}$} \\
\hline & 87.4 & 85.2 & 83.5 & 81.9 & & \\
\hline Cervicitis, $\mathrm{n}$ & 15 & 1 & 0 & 0 & 6.67 & 0.00 \\
\hline CIN I-III, n & 15 & 5 & 2 & 2 & 33.33 & 13.33 \\
\hline Cervical cancer, $\mathrm{n}$ & 15 & 5 & 3 & 3 & 33.33 & 20.00 \\
\hline$\chi^{2}$ & & & & & 3.85 & 3.15 \\
\hline P-value & & & & & 0.146 & 0.207 \\
\hline
\end{tabular}

The ratio of the samples with hypermutation to the total samples at the denaturation temperatures of 85.2 and $83.5^{\circ} \mathrm{C}$ were calculated. $\chi^{2}$ test was used for group comparison. HPV, human papilloma virus; CIN I-III, cervical intraepithelial neoplasia I, II, and III.

A
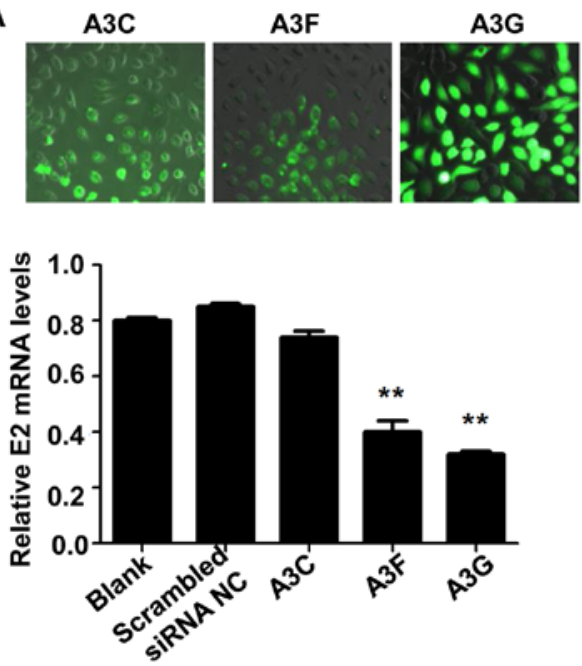

B

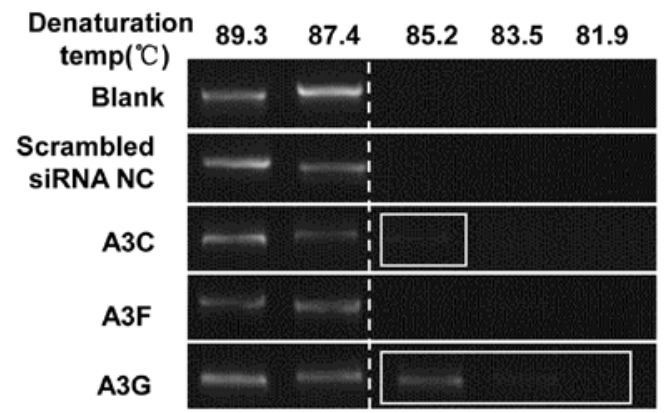

Figure 4. HPV16 E2 gene expression and hypermutation in SiHa cells transfected with APOBEC3s lentiviral vectors. (A) GFP-labeled A3C, A3F and A3G lentiviruses were transfected into SiHa cells and the fluorescence intensity was observed using an inverted fluorescence microscope to determine the transfection efficiency. Magnification, x200. The mRNA and protein expression levels of HPV16 E2 in A3 lentivirus-transfected SiHa cells were confirmed using reverse transcription-quantitative PCR and western blotting. (B) The HPV16 E2 genome hypermutation following lentiviral transfection was detected using the differential DNA Denaturation PCR. ${ }^{* *} \mathrm{P}<0.01$ vs. blank control or scrambled siRNA control. HPV, human papilloma virus; APBOEC3s, Apolipoprotein B mRNA-editing enzyme catalytic polypeptides; siRNA, small interfering RNA; NC, negative control; A3C, APOBEC3C; A3F, APOBEC3F; A3G, APOBEC3G; GFP, green fluorescent protein; C, cytosine; G, guanine; A, adenine; T, thymine.

lesions. The HPV16 is the most common genotype associated with cervical cancer (22). The HPV genome can be divided into the following three regions: The LCR, early region (E1, E2, E4, E5, E6 and E7) and late region (L1 and L2). The E2 gene regulates the processes of replication and transcription of
HPV DNA and is associated with the integration of the HPV genome into the host genome $(9,23,24)$. Furthermore, the E2 gene regulates the function and transformation of the E6 and E7 oncogenes (9). The A3s family is a class of endogenous natural immune protein molecules with antiviral capabilities (25). In 
Table III. Frequency of hypermutation base substitutions in SiHa cells following lentiviral transfection as detected by Sanger sequencing.

Frequency of base substitutions

\begin{tabular}{lcrc}
\cline { 2 - 4 } Variable & $\mathrm{G} \rightarrow \mathrm{A}$ & $\mathrm{C} \rightarrow \mathrm{T}$ & Other \\
\hline A3C & 34 & 56 & 2 \\
A3F & 0 & 3 & 1 \\
A3G & 2 & 126 & 4 \\
\hline
\end{tabular}

this study, our results showed that, during the progression of cervicitis to CIN I-III and then cervical cancer, the mRNA and protein expression levels of $\mathrm{A} 3 \mathrm{C}, \mathrm{A} 3 \mathrm{~F}$, and $\mathrm{A} 3 \mathrm{G}$ were significantly changed, suggesting that the members of the A3s family may be involved in the development of cervical cancer.

A potential role of A3 in viral infection is to edit the negative DNA strand generated during viral reverse transcription, deaminating the $\mathrm{C}$ into $\mathrm{U}$ and thereby causing the $\mathrm{C}>\mathrm{T}$ and $\mathrm{G}>\mathrm{A}$ hypermutation in the viral genome (25-29). Studies $(30,31)$ have demonstrated that $\mathrm{A} 3$ induced this hypermutation in viral DNA during HIV-1 replication, thereby inhibiting the HIV-1 reverse transcription and DNA integration. It has been shown that the $\mathrm{A} 3 \mathrm{G}$ overexpression (both mRNA and protein levels) induces HBV hypermutation and reduces HBV viral synthesis, and the frequency of hypermutations is increased with elevated A3G expression levels (both mRNA and protein) $(8,32)$. A large number of studies have confirmed that A3 induce mutations in the HIV and HBV genomes, thereby inhibiting viral replication; however, A3-induced mutation may also be a double-edged sword (33-36). A3 induce the innate immune response against the virus through targeted mutations, and meanwhile the A3 mutagenesis would induce the somatic cell mutation (31-38).

In the present study, 3D-PCR amplification and sequence analysis was performed on the HPV16 genome from cervical lesions of different grades. The results showed that there were $\mathrm{C}>\mathrm{T}$ and $\mathrm{G}>\mathrm{A}$ hypermutations in the HPV16 E2 gene in Uygur patients with cervicitis, CIN I-III and cervical cancer, which were typical types of mutations caused by the APOBEC3 family (25-29). However, in HPV16 E2 genomes isolated from clinical samples, there were small numbers of base substitution hypermutation, and there were no significant differences in the HPV16 E2 hypermutation statistical data between the clinical samples of the cervicitis, CIN I-III and cervical cancer groups. This may be because the integrated HPV does not expose enough single-stranded DNA regions required for the deaminase activity of A3 (30). Therefore, the poor ability of A3 to integrate into HPV E2 gene may also lead to reduced frequency of the A3-induced HPV16 hypermutation. Furthermore, in lesions expressing high levels of A3 during the transcription and replication, HPV16 may evolve into a mutant form possessing fewer A3 target sites $(39,40)$, and HPV16 may inhibit the antiviral activity of A3 (39,40).

Analysis of persistent HPV infection in a cervical keratinocyte model has demonstrated that $\mathrm{A} 3$ can induce hypermutations in the HPV16 genome $(37,40)$. Additionally, A3 are involved in the editing of HPV E2 hypermutation $(16,40,41)$. In the present study, SiHa cell models overexpressing A3 were established and these cells were subjected to HPV16 3D-PCR amplification and sequence analysis. The results demonstrated that $\mathrm{A} 3 \mathrm{G}$ overexpression induced the downregulated expression of the HPV16 E2 gene, and C $>$ T hypermutations were observed in the E2 gene. Compared with previous studies showing that A3 induces HIV hypermutation and inhibits viral replication $(5,6)$, the present study revealed that the frequency of the HPV E2 hypermutation in $\mathrm{SiHa}$ cells was lower, following overexpression of A3G. The high expression levels of A3 may lead to E2 hypermutations, but low frequencies of these hypermutations may not affect HPV16 replication. Studies have shown that A3 edits the HIV hypermutation and thus inhibits the virus replication $(4,5)$. Compared with the frequency of A3-induced HIV hypermutation, the frequency of HPV E2 region hypermutation in the SIHA cells high-expressed with A3G is relatively lower. Based on these findings, we speculate that the high A3s high expression leads to the E2 hypermutation, rather than affects the HPV16 replication. However, high A3G expression levels reduced the expression the E2 gene in SiHa cells. E2 is a key gene for the integration of HPV into the host cells, which may enhance the expression levels of E6 and E7 oncogenes (9). Therefore, A3G may regulate the integration of HPV into the host genome and function in the development of cervical cancer. This may improve the understanding of the molecular mechanisms underlying the development of cervical cancer.

There are several limitations of the present study. On one hand, the sample size was relatively small and it was difficult to verify the clinical significance of HPV16 hypermutation in the pathogenesis of cervical cancer. On the other hand, 3D-PCR technology could only detect the A/T-rich DNA sequence compared with the reference sequence in the detection of HPV16 hypermutation. Therefore, HPV16 genome-wide sequencing would be required to determine additional HPV16 mutations in clinical samples. In the future, in-depth studies using high-throughput sequencing technology, with an increased sequencing depth and larger sample size are required to comprehensively evaluate the biological significance of HPV16 hypermutations and the association of HPV infection with the development of cervical cancer.

\section{Acknowledgements}

Not applicable.

\section{Funding}

The present study was supported by the National Natural Science Foundation of China-Regional Science Fund (grant no. 81460395).

\section{Availability of data and materials}

The datasets used and/or analyzed during the present study are available from the corresponding author on reasonable request.

\section{Authors' contributions}

SS, HC and ZJ conducted the experiments, analyzed the data and wrote the manuscript. MN and LW conceived and 
designed the study and helped to revise the manuscript. All authors read and approved the final manuscript.

\section{Ethics approval and consent to participate}

Informed consent was provided by every patient and the present study was approved by The Ethics Review Board of the People's Hospital of Xinjiang Uygur Autonomous Region (Urumqi, China; approval no. 2014048).

\section{Patient consent for publication}

Not applicable.

\section{Competing interests}

The authors declare that they have no competing interests.

\section{References}

1. Warren CJ, Westrich JA, Doorslaer KV and Pyeon D: Roles of APOBEC3A and APOBEC3B in human papillomavirus infection and disease progression. Viruses 9: E233, 2017.

2. Salter JD, Bennett RP and Smith HC: The APOBEC protein family: United by structure, divergent in function. Trends Biochem Sci 41: 578-594, 2016.

3. Ikeda T, Symeonides M, Albin JS, Li M, Thali M and Harris RS: HIV-1 adaptation studies reveal a novel Env-mediated homeostasis mechanism for evading lethal hypermutation by APOBEC3G. PLoS Pathog 14: e1007010, 2018.

4. Ebrahimi D, Richards CM, Carpenter MA, Wang J, Ikeda T, Becker JT, Cheng AZ, McCann JL, Shaban NM, Salamango DJ, et al: Genetic and mechanistic basis for APOBEC $3 \mathrm{H}$ alternative splicing, retrovirus restriction, and counteraction by HIV-1 protease. Nat Commun 9: 4137, 2018.

5. Anderson BD, Ikeda T, Moghadasi SA, Martin AS, Brown WL and Harris RS: Natural APOBEC3C variants can elicit differential HIV-1 restriction activity. Retrovirology 15: 78, 2018.

6. Kim EY, Lorenzo-Redondo R, Little SJ, Chung YS, Phalora PK, Maljkovic Berry I, Archer J, Penugonda S, Fischer W, Richman DD, et al: Human APOBEC 3 induced mutation of human immunodeficiency virus type-1 contributes to adaptation and evolution in natural infection. PLoS Pathog 10: e1004281, 2014.

7. Luo J: Stable expression of porcine APOBEC3F in PK15 cells and its inhibitory effects on PERV mutation. Guangxi University 2012.

8. Noguchi C, Hiraga N, Mori N, Tsuge M, Imamura M, Takahashi S, Fujimoto Y, Ochi H, Abe H, Maekawa T, et al: Dual effect of APOBEC3G on Hepatitis B virus. J Gen Virol 88: 432-440, 2007.

9. Vieira VC, Leonard B, White EA, Starrett GJ, Temiz NA, Lorenz LD, Lee D, Soares MA, Lambert PF, Howley PM and Harris RS: Human papillomavirus E6 triggers upregulation of the antiviral and cancer genomic DNA deaminase APOBEC3B. mBio 5: e2234-14, 2014.

10. Bulliard Y, Narvaiza I, Bertero A, Peddi S, Röhrig UF Ortiz M, Zoete V, Castro-Diaz N, Turelli P, Telenti A, et al: Structure-function analyses point to a polynucleotide-accommodating groove essential for APOBEC3A restriction activities. J Virol 85: 1765-1776, 2011.

11. Tsuge M, Noguchi C, Akiyama R, Matsushita M, Kunihiro K, Tanaka S, Abe H, Mitsui F, Kitamura S, Hatakeyama T, et al: $\mathrm{G}$ to A hypermutation of TT virus. Virus Res 149: 211-216, 2010

12. Gee P, Ando Y, Kitayama H, Yamamoto SP, Kanemura Y, Ebina $\mathrm{H}$, Kawaguchi $\mathrm{Y}$ and Koyanagi Y: APOBEC1-mediated editing and attenuation of herpes simplex virus 1 DNA indicate that neurons have an antiviral role during herpes simplex encephalitis. J. Virol 85: 9726-9736, 2011.

13. Suspène R, Aynaud MM, Koch S, Pasdeloup D, Labetoulle M, Gaertner B, Vartanian JP, Meyerhans A and Wain-Hobson S: Genetic editing of herpes simplex virus 1 and Epstein-Barr herpesvirus genomes by human APOBEC 3 cytidine deaminases in culture and in vivo. J Virol 85: 7594-7602, 2011.
14. Lucifora J, Xia Y, Reisinger F, Zhang K, Stadler D, Cheng X, Sprinzl MF, Koppensteiner H, Makowska Z, Volz T, et al: Specifific and nonhepatotoxic degradation of nuclear hepatitis B virus cccDNA. Science 343: 1221-1228, 2014.

15. Hirose Y, Onuki M, Tenjimbayashi Y, Mori S, Ishii Y, Takeuchi T, Tasaka N, Satoh T, Morisada T, Iwata T, et al: Within-host variations of human papillomavirus reveal APOBEC signature mutagenesis in the viral genome. J Virol 92: e00017-18, 2018.

16. Stenglein MD, Burns MB, Li M, Lengyel J and Harris RS: APOBEC 3 proteins mediate the clearance of foreign DNA from human cells. Nat Struct Mol Biol 17: 222-229, 2010.

17. Kondo S, Wakae K, Wakisaka N, Nakanishi Y, Ishikawa K, Komori T, Moriyama-Kita M, Endo K, Murono S, Wang Z, et al: APOBEC 3A associates with human papillomavirus genome integration in oropharyngeal cancers. Oncogene 36: 1687-1697, 2017.

18. Graham SV: Human papillomavirus: Gene expression, regulation and prospects for novel diagnostic methods and antiviral therapies. Future Microbiol 5: 1493-1506, 2010.

19. Xue Y, Bellanger S, Zhang W, Lim D, Low J, Lunny D and Thierry F: HPV16 E2 is an immediate early marker of viral infection, preceding E7 expression in precursor structures of cervical carcinoma. Cancer Res 70: 5316-5325, 2010.

20. Bhatla N, Aoki D, Sharma DN and Sankaranarayanan R: Cancer of the cervix uteri. Int J Gynaecol Obstet 143 (Suppl 2): S22-S36, 2018.

21. Livak KJ and Schmittgen TD: Analysis of relative gene expression data using real-time quantitative PCR and the 2(-Delta Delta C(T)) method. Methods 25: 402-408, 2001.

22. de Sanjose S, Quint WG, Alemany L, Geraets DT, Klaustermeier JE, Lloveras B, Tous S, Felix A, Bravo LE, Shin HR, et al: Human papillomavirus genotype attribution in invasive cervical cancer: A retrospective cross-sectional worldwide study. Lancet Oncol 11: 1048-1056, 2010.

23. Pande S, Jain N, Prusty BK, Bhambhani S, Gupta S, Sharma R, Batra $S$ and Das BC: Human papillomavirus type 16 variant analysis of E6,E7, and L1 gennes and long control regin in biopsy samples from cervical cancer patients in North India. J Clin Microbiol 46: 1060-1066, 2008.

24. Franceschi S: The IARC commitment to cancer prevention: The example of papillomavirus and cervical cancer. Recent Results Cancer Res 166: 277-297, 2005.

25. Suspène R, Guétard D, Henry M, Sommer P, Wain-Hobson $S$ and Vartanian JP: Extensive editing of both hepatitis B virus DNA strands by APOBEC3 cytidine deaminases in vitro and in vivo. Proc Natl Acad Sci USA 102: 8321-8326, 2005.

26. Noguchi $C$, Ishino $H$, Tsuge $M$, Fujimoto $Y$, Imamura $M$, Takahashi S and Chayama K: G to A hypermutation of hepatitis B virus. Hepatology 41: 626-633, 2005.

27. Suspène R, Henry M, Guillot $S$, Wain-Hobson S and Vartanian JP: Recovery of APOBEC3-edited human immunodeficiency virus G->A hypermutants by differential DNA denaturation PCR. J Gen Virol 86: 125-129, 2005

28. Nik-Zainal S, Alexandrov LB, Wedge DC, Van Loo P, Greenman CD, Raine K, Jones D, Hinton J, Marshall J, Stebbings LA, et al: Mutational processes molding the genomes of 21 breast cancers. Cell 149: 979-993, 2012.

29. Alexandrov LB, Nik-Zainal S, Wedge DC, Aparicio SA, Behjati S, Biankin AV, Bignell GR, Bolli N, Borg A, Børresen-Dale AL, et al: Signatures of mutational processes in human cancer. Nature 500: 415-421, 2013.

30. Malim MH: APOBEC proteins and intrinsic resistance to HIV-1 infection. Philos Trans R Soc Lond B Biol Sci 364: 675-687, 2009.

31. Sheehy AM, Gaddis NC, Choi JD and Malim MH: Isolation of a human gene that inhibits HIV-1 infection and is suppressed by the viral Vif protein. Nature 418: 646-650, 2002.

32. Kitamura K, Wang Z, Chowdhury S, Simadu M, Koura M and Muramatsu M: Uracil DNA glycosylase counteracts APOBEC3G-induced hypermutation of hepatitis B viral genomes: Excision repair of covalently closed circular DNA. PLoS Pathog 9: e1003361, 2013.

33. Vieira VC and Soares MA: The role of cytidine deaminases on innate immune responses against human viral infections. Biomed Res Int 2013: 683095, 2013.

34. Nik-Zainal S, Wedge DC, Alexandrov LB, Petljak M, Butler AP, Bolli N, Davies HR, Knappskog S, Martin S, Papaemmanuil E, et al: Association of a germline copy number polymorphism of APOBEC $3 \mathrm{~A}$ and APOBEC 3B with burden of putative APOBEC-dependent mutations in breast cancer. Nat Genet 46: 487-491, 2014. 
35. Roberts SA, Sterling J, Thompson C, Harris S, Mav D, Shah R, Klimczak LJ, Kryukov GV, Malc E, Mieczkowski PA, et al: Clustered mutations in yeast and in human cancers can arise from damaged long single-strand DNA regions. Mol Cell 46: 424-435, 2012

36. Kazanov MD, Roberts SA, Polak P, Stamatoyannopoulos J, Klimczak LJ, Gordenin DA and Sunyaev SR: APOBEC-induced cancer mutations are uniquely enriched in early-replicating, gene-dense, and active chromatin regions. Cell Rep 13: $1103-1109,2015$

37. Roberts SA, Lawrence MS, Klimczak LJ, Grimm SA, Fargo D, Stojanov P, Kiezun A, Kryukov GV, Carter SL, Saksena G, et al: An APOBEC cytidine deaminase mutagenesis pattern is widespread in human cancers. Nat Genet 45: 970-976, 2013.

38. Burns MB, Lackey L, Carpenter MA, Rathore A, Land AM, Leonard B, Refsland EW, Kotandeniya D, Tretyakova N, Nikas JB, et al: APOBEC3B is an enzymatic source of mutation in breast cancer. Nature 494: 366-370, 2013.
39. Mussil B, Suspène R, Aynaud MM, Gauvrit A, Vartanian JP and Wain-Hobson S: Human APOBEC3A isoforms translocate to the nucleus and induce DNA double strand breaks leading to cell stress and death. PLoS One 8: e73641, 2013.

40. Wang Z, Wakae K, Kitamura K, Aoyama S, Liu G, Koura M, Monjurul AM, Kukimoto I and Muramatsu M: APOBEC3 deaminases induce hypermutation in human papillomavirus 16 DNA upon beta interferon stimulation. J Virol 88: 1308-1317, 2014.

41. Burns MB, Temiz NA and Harris RS: Evidence for APOBEC3B mutagenesis in multiple human cancers. Nat Genet 45: 977-983, 2013.

(i) (3) This work is licensed under a Creative Commons Attribution-NonCommercial-NoDerivatives 4.0 International (CC BY-NC-ND 4.0) License. 